\title{
CDC6 wt Allele
}

National Cancer Institute

\section{Source}

National Cancer Institute. CDC6 wt Allele. NCI Thesaurus. Code C52294.

Human CDC6 wild-type allele is located in the vicinity of $17 q 21.3$ and is approximately 15 $\mathrm{kb}$ in length. This allele, which encodes cell division control protein 6 homolog, is involved in the regulation of both chromosomal replication and cell cycle progression. 